\title{
Characterization of novel Trichoderma spp. isolates as a search for effective biocontrollers of fungal diseases of economically important crops in Argentina
}

\author{
Verónica Fabiana Consolo • Cecilia Inés Mónaco • \\ Cristina Alicia Cordo $\cdot$ Graciela Lidia Salerno
}

Received: 18 July 2011/Accepted: 28 October 2011/Published online: 17 November 2011

(C) Springer Science+Business Media B.V. 2011

\begin{abstract}
Monoconidial cultures of 33 isolates of Trichoderma from Buenos Aires Province, Argentina were characterized on the basis of twenty eight morphological, physiological and biochemical features. All of them were screened for proteinase, endochitinase and $\beta-1,3$ glucanase activity. Universally primed PCR (UP-PCR) and intersimple sequence repeat (ISSR) techniques were used to examine the genetic variability among isolates, which resulted in 127 bands for the total number of isolates. These results were subjected to numerical analysis revealing 20 haplotypes grouped in five clusters. The ability of Trichoderma isolates to antogonize soil-borne fungal plant pathogens using a dual culture assay was done against five fungal species: Alternaria sp., Bipolaris sorokiniana, Fusarium graminearum, F. solani, and Pyricularia oryzae. The highest inhibition values $(85 \% \mathrm{RI})$ were obtained against $B$. sorokiniana and $P$. oryzae. Three isolates of $T$. harzianum named as FCCT2, FCCT3 and FCCT9 were capable of causing a high growth inhibition on four of the fungal species assayed, which was in agreement with their higher extracellular hydrolytic activity. Our results suggest that these isolates have the potential to be effective agents for biocontrol of cereal and tomato fungal pathogens.
\end{abstract}

\footnotetext{
V. F. Consolo $(\square)$. G. L. Salerno

Centro de Estudios de Biodiversidad y Biotecnología (INBA-CONICET), Centro de Investigaciones Biológicas, Fundación para Investigaciones Biológicas Aplicadas (CEBB-CIB-FIBA), C.C. 1348, 7600 Mar del Plata, Argentina e-mail: faconsolo@fiba.org.ar

C. I. Mónaco - C. A. Cordo

CIDEFI, Facultad de Ciencias Agrarias y Forestales,

Universidad Nacional de La Plata, Calle 60 y 119 ,

1900 La Plata, Argentina
}

Keywords Biocontrol · Characterization · Phytopathogens - Trichoderma spp.

\section{Introduction}

Species of the genus Trichoderma (Ascomycota, Hypocreales) comprise a great number of fungal strains with economic importance mainly as biological control agents (BCAs). These soil-borne free-living microorganisms are non pathogenic fungi, which can also colonize roots of numerous plants. They are recognized for their important benefits to agriculture such as their ability to protect crops against diseases and to increase crop yield under field conditions (Harman et al. 2004). So far, Trichoderma spp. are among the biocontrollers commercially marketed as biopesticides, biofertilizers and soil amendments (Harman et al. 2004; Lorito et al. 2004). Several mechanisms have been suggested as being responsible for the control of plant disease by Trichoderma isolates. It was reported that they are capable of producing extracellular lytic enzymes such as chitinases, glucanases and proteases (Chet and Chernin 2002; Viterbo et al. 2002). This observation, together with the fact that chitin and $\beta-1,3$ glucan are the main structural components of fungal cell wall, suggests that chitinases and $\beta-1,3$ glucanases produced by some Trichoderma isolates are key enzymes in the lysis of cell walls during mycoparasitic action, being most frequently considered playing an important role in biocontrol (Kullnig et al. 2000; Kubicek et al. 2001). On the other hand, Trichoderma proteases have been reported to play a role in the host lysis by attacking lipids and proteins, which are also part of the cell-wall skeleton. Also Trichoderma spp. strains produce antifungal antibiotics (Ghisalberti and Rowland 1993), may be competitors to fungal pathogens (Grondona et al. 1997), 
promote plant growth (Vinale et al. 2004), and induce plant defence responses in plants (Harman et al. 2004).

Most Trichoderma species grow rapidly in artificial culture media and produce large number of small green or white conidia from conidiophores. The most common strains of Trichoderma genus used as BCAs are T. virens, T. viride and above all, T. harzianum (Grondona et al. 1997). There is an increasing interest in this genus because of its biological properties against soil-borne plant pathogenic fungi and commercialization as biopesticides, biofertilizers and soil amendments (Harman et al. 2004; Lorito et al. 2004).

Knowledge concerning the behaviour of Trichoderma as antagonists is not only essential for their effective use but also because there is a need for a more precise characterization of the isolates. Several attempts to assess genetic diversity have been used for the characterization and grouping of isolates including isozyme analysis (Stasz et al. 1989; Leuchtmann et al. 1996), polymerase chain reaction (PCR) fingerprinting and sequence analysis (Zimand et al. 1994; Kuhls et al. 1995; Turner et al. 1997; Bulat et al. 1998), random DNA (RAPD)-like PCR fingerprinting method and universally primed PCR (UP-PCR) (Cumagun et al. 2000). Another method that could be used to assess genetic diversity within and among fungi is non-anchored inter simple sequence repeat (ISSR). This technique consists on the amplification of DNA sequences between simple sequence repeats by means of homologous primers without previous knowledge of the sequence, generating specific and reproducible patterns (Bornet and Branchard 2001). The use of these techniques for genetic diversity assessments helps to eliminate duplicated strains in programs for microbial selection (Samson 1995), and during mass production and maintenance of long-term cultures, which could lead to contamination (Markovic and Markovic 1998) or mutation (Becker and Schwinn 1993).

Although around the world several fungicides based on formulation of Trichoderma have been commercialized in the last few years, there is still appreciable interest on finding and formulating more efficient products based on this fungus. Particularly, in Argentina commercial products based on Trichoderma have been recently registered and used as BCA and plant growth promoters. To select more effective and antagonistic strains for biocontrol ability, a completely characterization under a range of conditions, and strictly selection and evaluation should be done. Understanding both the genetic diversity of strains within Trichoderma species and their mechanisms of biocontrol will lead to improve the application of the different strains as BCAs. Because the value of a selected BCA will also depend on the applicability of isolates to different ecozones (Grondona et al. 1997) there is still interest in finding novel native strains with potential biological control activity.
The aim of this study was to isolate and select novel native strains of Trichoderma spp. from different agricultural systems of Buenos Aires Province, Argentina, with high quality as potential plant fungal controllers. We examined morphological, biochemical, physiological and molecular features of the isolates in addition to their ability as antifungals against five plant pathogens, important fungal pests of agricultural products.

\section{Materials and methods}

Isolation and identification of Trichoderma spp.

Nineteen soil samples were collected using a cylindrical tube, from different agroecosystems in Buenos Aires Province, Argentina, during 2007-2008 (Table 1). Each sample was taken randomly at $20 \mathrm{~cm}$ soil depth and stored at $4^{\circ} \mathrm{C}$ within a period of 1 month. The serial dilution technique was used for Trichoderma isolation (Elad et al. 1981). One $\mathrm{ml}$ of $10^{-3}$ soil dilution was plated on selective medium using rose bengal and pentachloronitrobenzene, and incubated at $28^{\circ} \mathrm{C}$ for 5-7 days. From colonies determined as Trichoderma according to Samuels et al. (2009), monoconidial isolates were obtained by transferring a germinated conidium on potato dextrose agar medium (PDA).

\section{DNA extraction}

Each Trichoderma isolate was grown for 5 days at room temperature in $50 \mathrm{ml}$ of liquid malt extract medium on a orbital shaker. Mycelia were harvested under vacuum and lyophilized. About $100 \mathrm{mg}$ of powered mycelia were used for DNA extraction following a modified version of the cetyltrimethylammonium bromide (CTAB) method (Murray and Thompson 1980), as follows. In total, $750 \mu \mathrm{l}$ of extraction buffer $(100 \mathrm{mM}$ Tris- $\mathrm{HCl}, \mathrm{pH} 8,100 \mathrm{mM}$ EDTA, $250 \mathrm{mM} \mathrm{NaCl}$, and $2 \% \mathrm{CTAB}$ ) and $15 \mu \mathrm{l}$ of 2-mercaptoethanol were added to the lyophilized mycelia and incubated at $65^{\circ} \mathrm{C}$ for $30 \mathrm{~min}$. Cellular proteins were precipitated with $300 \mu \mathrm{l}$ of $3 \mathrm{M}$ potassium acetate ( $\mathrm{pH} 4.8$ ). After centrifugation at maximum speed in a microcentrifuge (Hermle Labortechnik GmbH, Wehingen, Germany), the supernatant was transferred to a new tube and extracted with $500 \mu \mathrm{l}$ of phenol:chloroform:isoamyl alcohol (25:24:1) and chloroform:isoamyl alcohol (24:1) until the interface became transparent. Nucleic acids were precipitated by adding $750 \mu \mathrm{l}$ of cold isopropanol followed by incubation at $4^{\circ} \mathrm{C}$ for $30 \mathrm{~min}$. After centrifugation at $17,500 \mathrm{~g}$ for $5 \mathrm{~min}$, the pellet was rinsed twice with $500 \mu \mathrm{l}$ of $70 \%$ ethanol, air-dried and dissolved in $100 \mu \mathrm{l}$ of Tris-EDTA buffer (10 mM Tris- $\mathrm{HCl} \mathrm{pH} 8$ and $1 \mathrm{mM}$ EDTA). DNA quality was determined by electrophoresis on $0.9 \%$ agarose gel. 
Table 1 Identification of Trichoderma isolates from soils of Buenos Aires Province, Argentina

\begin{tabular}{|c|c|c|c|c|c|c|}
\hline Strain & Soil source & Field location & Year of collection & Closest species match & Accession code & Similarity $(\%)$ \\
\hline FCCT1 & Soybean & Azul & 2007 & T. harzianum & HE601545 & 99 \\
\hline FCCT2 & Soybean & Azul & 2007 & T. harzianum & HE601546 & 98 \\
\hline FCCT3 & Soybean & Azul & 2007 & T. harzianum & HE608884 & 98 \\
\hline FCCT4 & Soybean & Azul & 2007 & T. harzianum & HE608893 & 98 \\
\hline FCCT5 & Soybean & Azul & 2007 & T. harzianum & HE608885 & 98 \\
\hline FCCT6 & Soybean & Azul & 2007 & T. koningii & HE608894 & 98 \\
\hline FCCT7 & Soybean & Azul & 2007 & T. koningii & HE608895 & 98 \\
\hline FCCT8 & Soybean & Azul & 2007 & T. harzianum & HE608896 & 99 \\
\hline FCCT9 & Soybean & Azul & 2007 & T. harzianum & HE608897 & 99 \\
\hline FCCT10 & Soybean & Azul & 2007 & T. harzianum & HE608886 & 86 \\
\hline FCCT11 & Rice & La Plata & 2007 & T. virens & HE608898 & 98 \\
\hline FCCT12 & Rice & La Plata & 2007 & T. virens & HE608899 & 98 \\
\hline FCCT13 & Rice & La Plata & 2007 & T. virens & HE608900 & 98 \\
\hline FCCT14 & Corn & Sierra de Los Padres & 2008 & T. harzianum & HE608901 & 99 \\
\hline FCCT15 & Corn & Sierra de Los Padres & 2008 & T. harzianum & HE608902 & 99 \\
\hline FCCT16 & Corn & Sierra de Los Padres & 2008 & T. harzianum & HE608911 & 99 \\
\hline FCCT17 & Corn & Balcarce & 2008 & T. harzianum & HE608892 & 80 \\
\hline FCCT18 & Corn & Balcarce & 2008 & T. harzianum & HE608912 & 99 \\
\hline FCCT19 & Corn & Balcarce & 2008 & T. harzianum & HE608887 & 99 \\
\hline FCCT20 & Corn & Balcarce & 2008 & T. harzianum & HE608890 & 99 \\
\hline FCCT21 & Corn & Sierra de Los Padres & 2008 & T. harzianum & HE608888 & 99 \\
\hline FCCT22 & Corn & Sierra de Los Padres & 2008 & T. harzianum & HE608913 & 99 \\
\hline FCCT23 & Corn & Sierra de Los Padres & 2008 & T. harzianum & HE608914 & 99 \\
\hline FCCT24 & Corn & Sierra de Los Padres & 2008 & T. harzianum & HE608891 & 98 \\
\hline FCCT25 & Corn & Sierra de Los Padres & 2008 & T. harzianum & HE608889 & 99 \\
\hline FCCT26 & Corn & Sierra de Los Padres & 2008 & T. virens & HE608903 & 89 \\
\hline FCCT27 & Corn & Sierra de Los Padres & 2008 & T. virens & HE608904 & 89 \\
\hline FCCT28 & Corn & Sierra de Los Padres & 2008 & T. virens & HE608905 & 99 \\
\hline FCCT29 & Corn & Sierra de Los Padres & 2008 & T. virens & HE608906 & 97 \\
\hline FCCT30 & Corn & Sierra de Los Padres & 2008 & T. virens & HE608907 & 97 \\
\hline FCCT31 & Corn & Sierra de Los Padres & 2008 & T. virens & HE608908 & 97 \\
\hline FCCT32 & Corn & Sierra de Los Padres & 2008 & T. virens & HE608909 & 97 \\
\hline FCCT33 & Corn & Sierra de Los Padres & 2008 & T. virens & HE608910 & 97 \\
\hline
\end{tabular}

PCR amplification of fungal-specific genes

Polymerase chain reaction (PCR) amplification of internal transcribed spacers (ITS) of the ribosomal DNA (rDNA) region from each Trichoderma isolate was performed with primers ITS1 (5'-TCCGTAGGTGAACCTGCGG-3') and ITS4 (5'-TCCTCCGCTTATTGATATGC-3') (White et al. 1990). Each amplified fragment includes the ITS1, the $5.8 \mathrm{~S}$ rDNA gene and the ITS2 regions. PCR was conducted in a mixture containing $10 \mathrm{ng}$ of genomic DNA, $20 \mathrm{mM}$ Tris$\mathrm{HCl}(\mathrm{pH} 8.4), 50 \mathrm{mM} \mathrm{KCl}, 1.5 \mathrm{mM} \mathrm{MgCl} 2,0.2 \mathrm{mM}$ each of the four dNTPs, $0.5 \mathrm{mM}$ of each primer, and 1 unit of Taq polymerase (Invitrogen, Carlsbad, CA, USA). Thermal cycling conditions involved an initial denaturation step at $94^{\circ} \mathrm{C}$ for $2.5 \mathrm{~min}$, followed by 40 cycles of $94^{\circ} \mathrm{C}$ for $15 \mathrm{~s}$, $48^{\circ} \mathrm{C}$ for $1 \mathrm{~min}$ and $72^{\circ} \mathrm{C}$ for $1.5 \mathrm{~min}$, and a final extension at $72^{\circ} \mathrm{C}$ for $10 \mathrm{~min}$. PCR products were separated by electrophoresis in a gel containing $1 \%$ agarose (Invitrogen Carlsbad, CA, USA) in $1 \times$ TAE buffer $(40 \mathrm{mM}$ Tris $-\mathrm{HCl}$, $\mathrm{pH} 8$, and $2 \mathrm{mM}$ EDTA). Gels were run for $1 \mathrm{~h}$ at $120 \mathrm{~V}$, stained with ethidium bromide and photographed with a Fotodyne system (Hartland, WI, USA).

DNA sequencing and data analysis

PCR amplification products were purified and sequenced by Macrogen (Korea) using primer ITS4. Each sequence was entered in Genbank and compared with those of known origin by using the BLAST search program (Altschul et al. 1997). All the sequences obtained in this 
study were deposited in the European Molecular Biology Laboratory (EMBL) and assigned accession numbers listed in Table 1.

\section{Morphology}

Colony diameter on PDA, mycelium and chlamydospore production, and conidium sizes were examined and registered.

\section{Physiological characterization}

\section{Growth at different temperatures and $\mathrm{pH}$ values}

The ability of Trichoderma isolates to grow at 4, 37 and $40^{\circ} \mathrm{C}$ over 14 days was tested on PDA, and the thermal resistance of the spore suspensions was determined after 5 min incubation at $75^{\circ} \mathrm{C}$ (Grondona et al. 1997). Growth

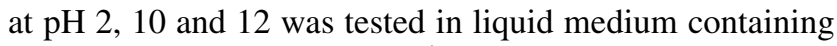
$0.05 \mathrm{~g}$ bromocresol purple $1^{-1}$ (Bridge 1985).

\section{Assimilation of nitrogen sources}

Growth, sporulation and pigment production were determined on solid media containing ammonium oxalate, sodium nitrite, creatine or urea. Plates were incubated at $24 \pm 2^{\circ} \mathrm{C}$ and evaluated after 14 days (Bridge 1985; Grondona et al. 1997).

\section{Assimilation of carbon sources}

Growth and sporulation in liquid medium with citric acid, glucose, ethanol or lactose as sole carbon sources were performed in the presence of 0.005 or $0.001 \%$ crystal violet, according to Bridge (1985).

Assay of inhibition of plant pathogenic fungi on agar

The fungi Alternaria sp., Bipolaris sorokiniana, Fusarium graminearum were selected because they cause major foliar disease and grain discoloration on cereals. They mainly affect wheat yield in Buenos Aires Province (Galich 1997). Conversely, $F$. solani causes wilt and basal root rot on tomato (Dal Bó et al. 2010). All these fungi were kindly provided by Centro de Estudios en Fitopatologia (CIDEFI), Facultad Agronomia, Universidad Nacional de La Plata. The fungus Pyricularia oryzae is responsible for the most important rice disease (blast) in Argentina (Consolo et al. 2008). The P. oryzae isolate used in the bioassays was from the Fundación para Investigaciones Biológicas Aplicadas Culture Collection (FCC). Fungal isolates were incubated on PDA at $25^{\circ} \mathrm{C}$ for 6 days, before being used in inhibition assays.
Biocontrol assays were performed on PDA plates using a dual culture technique (Grondona et al. 1997) by inoculating each Trichoderma isolate with one of the five fungal plant pathogens mentioned above. Each host fungus and the Trichoderma isolates were grown on PDA plates for a week at $26 \pm 2{ }^{\circ} \mathrm{C}$. Blocks of the target fungus were cut from the periphery and transferred to a petri dish. After $48 \mathrm{~h}$ of growth of the target fungus, a block of each Trichoderma isolate was transferred in the same plate separated by about $3 \mathrm{~cm}$. Plates were incubated at $26 \pm 2{ }^{\circ} \mathrm{C}$ for 7 days and observed periodically. Inhibition was registered as presence of an inhibition zone prior to any mycelial contact. The percentage of ratio inhibition (RI) was calculated as follows: $\mathrm{RI}=100 \times\left(R_{2}-R_{1}\right) / R_{2}$ (Watts et al. 1988), where $R_{1}$ was the distance between the inoculum of the pathogen and the edge of colony measured in the direction of the inoculum of the Trichoderma isolate, and $R_{2}$ was the colony growth of the pathogen measured in the direction of maximum radius. RI value was the mean of three replicates per isolate. Microscopic examinations were done on the area of intermingling contact (pathogenantagonist).

Determination of enzyme activities from Trichoderma spp.

Aesculin, starch, Tween 80 , gelatin hydrolysis and reduction of tetrazolium were tested on solid media as previously described (Lynch et al. 1981; Bridge 1985; Grondona et al. 1997).

To determine specific activity of secreted proteinase, endochitinase and $\beta-1,3$ glucanase, isolates were grown on Vogel's Medium for $48 \mathrm{~h}$ at room temperature at $150 \mathrm{rev}$ $\min ^{-1}$ and centrifuged. Culture filtrates were used for enzymatic activity determination. The activity of $\beta-1,3$ glucanase was assayed in the presence of $0.5 \%(\mathrm{w} / \mathrm{v})$ laminarin (Sigma) in $50 \mathrm{mM}$ sodium acetate buffer $(\mathrm{pH}$ 5.5) and reducing-sugar content was quantified by Somogyi and Nelson's method after 30 min incubation at $37^{\circ} \mathrm{C}$ (de la Cruz et al. 1995). Endochitinase activity was detected using the highly sensitive substrate 4-methylumbelliferyl $\beta$-D- $N, \quad N^{\prime}, \quad N^{\prime \prime}$-triacetylchitotriose (Sigma) after $30 \mathrm{~min}$ incubation at $37^{\circ} \mathrm{C}$ (Baek et al. 1999). Proteinase activity was determined in the presence of the synthetic substrate $N$-Succinyl-Ala-Ala-Pro-Phe $p$-nitroanilide (Sigma) after 30 min incubation at $37^{\circ} \mathrm{C}$ (St. Leger et al. 1987; Bindschedler et al. 2002). One unit of $\beta-1,3$ glucanase or endochitinase activity was defined as the amount of enzyme required to release $1 \mu \mathrm{M}$ of glucose equivalents or of 4-methyl umbelliferone per min, respectively, and one unit of protease activity was defined as an increase of 1 OD unit at $410 \mathrm{~nm}$ produced by $10 \mu \mathrm{g}$ of protein in $30 \mathrm{~min}$. 
Protein concentration was determined by the Bradford method using bovine serum albumin as standard.

Genetic variability of Trichoderma isolates

Twelve ISSR primers (Stenglein and Balatti 2006; Moreno et al. 2008) and four UP-PCR primers (Cumagun et al. 2000) were tested to analyse genetic diversity among Trichoderma isolates (Table 2). PCRs for ISSR primers were performed in an Eppendorf Gradient Mastercycler in a $20 \mu \mathrm{l}$ final volume, containing $10 \mathrm{ng}$ of genomic DNA, $20 \mathrm{mM}$ Tris- $\mathrm{HCl}$ (pH 8.4), $50 \mathrm{mM} \mathrm{KCl,} 1.5 \mathrm{mM} \mathrm{MgCl}_{2}$, $0.2 \mathrm{mM}$ each of the four dNTPs, $2.5 \mathrm{mM}$ of each primer, and 1 unit of Taq polymerase (Invitrogen, Carlsbad, CA). Thermal cycling conditions involved an initial denaturation step at $94^{\circ} \mathrm{C}$ for $7 \mathrm{~min}$, followed by 33 cycles at $94^{\circ} \mathrm{C}$ for $60 \mathrm{~s}, 48^{\circ} \mathrm{C}$ for $75 \mathrm{~s}$, and $72^{\circ} \mathrm{C}$ for $4 \mathrm{~min}$. A final extension step of $72^{\circ} \mathrm{C}$ for $7 \mathrm{~min}$ was added. The same procedure was followed for amplification reactions for UP-PCR primers except for primer annealing that was $56^{\circ} \mathrm{C}$. Fifteen $\mu \mathrm{l}$ of PCR products were separated by electrophoresis in a gel containing $1.5 \%$ agarose (Invitrogen Carlsbad, CA, USA) in $1 \times$ TAE buffer (40 mM Tris-HCl, pH 8 , and $1 \mathrm{mM}$ EDTA). Gels were run for $3-4 \mathrm{~h}$ at $100 \mathrm{~V}$, stained with ethidium bromide, and photographed with a Fotodyne system (Hartland, WI, USA).

\section{Data analysis}

Morphological tests were coded as on an "all present" system, where 0 is negative and 1 is positive. Physiological and biochemical tests on solid media were coded as 0 or negative and 1 as positive reaction. Twenty eight characters were evaluated from morphological, physiological and biochemical test.

To determine the genetic relationship among isolates, the presence or absence of amplified fragments was scored manually and was converted into binary data. Two similarity matrices were calculated using the DICE coefficient (SD) (Sneath and Sokal 1973). One of the matrices was based on morphological, physiological and biochemical features, and the other one was constructed with fingerprint data. Cluster analysis based on the unweighted pair group method of averages (UPGMA) (Sneath and Sokal 1973) was performed using NTSYS software, version 2.0 (Rohlf 1998) and a dendrogram was constructed. The cophenetic correlation coefficient was used as a measure of goodness of fit for the cluster analysis. The combined set of morphological, physiological, biochemical and fingerprint data matrices were used to analyse the relationship between characters. A matrix comparison with 1,000 permutations was conducted using the Mantel test (Mantel 1967).

\section{Results}

Morphological features

Thirty three isolates of Trichoderma were obtained from nineteen samples collected on soybean, corn and rice soils from different fields located in Buenos Aires Province, Argentina. The identification based on ITS sequences and BLAST searches revealed three Trichoderma species: T. harzianum (20 isolates), T. virens (11 isolates) and T. koningii (2 isolates) (Table 1). Morphological characters were generally found to be highly variable within and between Trichoderma species. All isolates produced colonies larger than $8.1 \mathrm{~cm}$ on PDA medium, and developed aerial mycelia and conidia $>2 \mu \mathrm{m}$ diameter. Only the isolate named FCCT1 was able to produce abundant chlamydospores of about $11.5 \mu \mathrm{m}$.

Physiological features

It was observed that Trichoderma strains showed different growth at different temperatures. Except for FCCT2, FCCT19 and FCCT31 that only grew at $26^{\circ} \mathrm{C}$, the other strains developed not only at $26^{\circ} \mathrm{C}$ but also at $37^{\circ} \mathrm{C}$. In addition, none of the isolates was capable of growing at 4 or $40^{\circ} \mathrm{C}$, but spores of them resulted resistant to temperatures as high as $75^{\circ} \mathrm{C}$. The isolates did not show growth on media at $\mathrm{pH} 2,10$ or 12 .

In solid media containing different nitrogen sources, only three isolates were capable of growing with ammonium oxalate or creatine but none of them grew with sodium nitrite or urea. Whereas all isolates developed on the media containing the different carbon sources, only nine isolates produced orange pigments on medium containing citric acid, glucose or ethanol.

In vitro inhibition assays

When we observed in vitro growth of five plant fungus pathogens, marked inhibition occurred in the presence of most of the 33 Trichoderma isolates. This test showed variations in the percentage of inhibition of radial growth of the soil-borne fungal plant pathogens (Table 2). The highest inhibition values (85\% RI) were obtained against B. sorokiniana and $P$. oryzae with the isolates FCCT3 and FCCT9, respectively. Maximum RI percentage $(62.5 \%)$ against Alternaria sp. was observed with isolates FCCT5 and FCCT8. For $F$. graminearum and $F$. solani the highest RI values were obtained with isolates FCCT2 and FCCT9 $(61 \%)$, and FCCT2 and FCCT3 (57\%). On the area of intermingling contact (pathogen-antagonist) differences in hyphal morphology of the pathogen as vacuolization of hyphae, plasmolysis of mycelium or coiling were observed. 
Table 2 Inhibition effects of Trichoderma isolates on some phytopathogenic fungi

\begin{tabular}{|c|c|c|c|c|c|}
\hline Trichoderma isolates & Alternaria sp. & Bipolaris sorokiniana & Fusarium graminearum & F. solani & Pyricularia oryzae \\
\hline FCCT1 & $37.50 \pm 0.00$ & $51.00 \pm 0.70$ & $45.00 \pm 0.50$ & $51.00 \pm 0.01$ & $38.00 \pm 0.00$ \\
\hline FCCT2 & $37.50 \pm 0.01$ & $62.50 \pm 0.45$ & $61.00 \pm 0.00$ & $57.00 \pm 0.00$ & $72.00 \pm 0.70$ \\
\hline FCCT3 & $50.00 \pm 0.00$ & $85.00 \pm 0.00$ & $25.50 \pm 0.10$ & $57.00 \pm 0.01$ & $69.00 \pm 0.51$ \\
\hline FCCT4 & $50.00 \pm 0.11$ & $42.00 \pm 0.01$ & $32.50 \pm 0.45$ & $42.00 \pm 0.40$ & $69.00 \pm 0.00$ \\
\hline FCCT5 & $62.50 \pm 0.00$ & $71.00 \pm 0.01$ & $32.50 \pm 0.50$ & $37.00 \pm 0.30$ & $69.00 \pm 0.10$ \\
\hline FCCT6 & $32.50 \pm 0.00$ & $71.00 \pm 0.20$ & $42.00 \pm 0.01$ & $50.00 \pm 0.40$ & $52.00 \pm 0.25$ \\
\hline FCCT7 & $52.00 \pm 0.22$ & $42.00 \pm 0.02$ & $50.00 \pm 0.00$ & $50.00 \pm 0.02$ & $64.60 \pm 0.50$ \\
\hline FCCT8 & $62.50 \pm 0.15$ & $42.00 \pm 0.25$ & $32.50 \pm 0.25$ & $50.00 \pm 0.01$ & $69.00 \pm 0.20$ \\
\hline FCCT9 & $37.50 \pm 0.10$ & $28.00 \pm 0.00$ & $61.00 \pm 0.40$ & $57.00 \pm 0.0$ & $85.00 \pm 0.01$ \\
\hline FCCT10 & $45.00 \pm 0.00$ & $45.00 \pm 0.00$ & $30.00 \pm 0.10$ & $42.00 \pm 0.01$ & $72.00 \pm 0.35$ \\
\hline FCCT11 & $27.50 \pm 0.20$ & $62.50 \pm 0.00$ & $35.00 \pm 0.40$ & $51.00 \pm 0.20$ & $42.00 \pm 0.20$ \\
\hline FCCT12 & $37.50 \pm 0.11$ & $45.00 \pm 0.15$ & $35.00 \pm 0.10$ & $28.00 \pm 0.25$ & $42.00 \pm 0.01$ \\
\hline FCCT13 & $37.50 \pm 0.50$ & $85.00 \pm 0.15$ & $32.50 \pm 0.25$ & $50.00 \pm 0.10$ & $71.00 \pm 0.02$ \\
\hline FCCT14 & $32.50 \pm 0.50$ & $74.00 \pm 0.20$ & $51.00 \pm 0.20$ & $45.70 \pm 0.10$ & $35.00 \pm 0.22$ \\
\hline FCCT15 & $28.50 \pm 0.30$ & $62.50 \pm 0.15$ & $35.00 \pm 0.20$ & $42.00 \pm 0.00$ & $51.50 \pm 0.20$ \\
\hline FCCT16 & $28.50 \pm 0.20$ & $71.00 \pm 0.10$ & $45.00 \pm 0.25$ & $45.70 \pm 0.00$ & $45.50 \pm 0.42$ \\
\hline FCCT17 & $28.50 \pm 0.25$ & $42.00 \pm 0.70$ & $41.50 \pm 0.15$ & $28.00 \pm 0.40$ & $80.00 \pm 0.00$ \\
\hline FCCT18 & $28.50 \pm 0.40$ & $71.00 \pm 0.65$ & $38.00 \pm 0.25$ & $28.00 \pm 0.25$ & $74.60 \pm 0.01$ \\
\hline FCCT19 & $28.50 \pm 0.40$ & $70.00 \pm 0.50$ & $35.00 \pm 0.30$ & $40.00 \pm 0.20$ & $72.00 \pm 0.02$ \\
\hline FCCT20 & $28.50 \pm 0.11$ & $74.00 \pm 0.00$ & $48.00 \pm 0.01$ & $37.00 \pm 0.10$ & $78.40 \pm 0.35$ \\
\hline FCCT21 & $31.40 \pm 0.15$ & $62.50 \pm 0.01$ & $27.50 \pm 0.30$ & $45.70 \pm 0.15$ & $41.50 \pm 0.12$ \\
\hline FCCT22 & $57.10 \pm 0.35$ & $62.50 \pm 0.01$ & $32.00 \pm 0.40$ & $37.00 \pm 0.30$ & $39.50 \pm 0.25$ \\
\hline FCCT23 & $17.40 \pm 0.45$ & $62.50 \pm 0.02$ & $48.50 \pm 0.30$ & $42.00 \pm 0.10$ & $74.60 \pm 0.35$ \\
\hline FCCT24 & $42.80 \pm 0.11$ & $62.50 \pm 0.01$ & $45.00 \pm 0.00$ & $42.00 \pm 0.01$ & $74.60 \pm 0.22$ \\
\hline FCCT25 & $42.80 \pm 0.15$ & $28.00 \pm 0.00$ & $31.50 \pm 0.00$ & $42.00 \pm 0.00$ & $74.60 \pm 0.14$ \\
\hline FCCT26 & $28.50 \pm 0.70$ & $54.20 \pm 0.20$ & $29.50 \pm 0.01$ & $42.00 \pm 0.25$ & $55.50 \pm 0.10$ \\
\hline FCCT27 & $28.50 \pm 0.25$ & $62.50 \pm 0.60$ & $42.00 \pm 0.20$ & $50.10 \pm 0.0$ & $50.10 \pm 0.02$ \\
\hline FCCT28 & $40.00 \pm 0.45$ & $60.00 \pm 0.50$ & $37.00 \pm 0.01$ & $42.80 \pm 0.20$ & $45.00 \pm 0.00$ \\
\hline FCCT29 & $25.00 \pm 0.10$ & $35.00 \pm 0.20$ & $35.00 \pm 0.20$ & $50.10 \pm 0.20$ & $35.10 \pm 0.00$ \\
\hline FCCT30 & $28.50 \pm 0.10$ & $52.00 \pm 0.15$ & $34.50 \pm 0.40$ & $28.50 \pm 0.40$ & $39.30 \pm 0.45$ \\
\hline FCCT31 & $35.00 \pm 0.25$ & $55.00 \pm 0.25$ & $21.00 \pm 0.01$ & $40.00 \pm 0.00$ & $55.00 \pm 0.30$ \\
\hline FCCT32 & $37.50 \pm 0.25$ & $57.00 \pm 0.00$ & $32.50 \pm 0.05$ & $42.80 \pm 0.15$ & $52.00 \pm 0.02$ \\
\hline FCCT33 & $37.50 \pm 0.25$ & $62.50 \pm 0.00$ & $32.50 \pm 0.40$ & $42.80 \pm 0.10$ & $55.00 \pm 0.00$ \\
\hline
\end{tabular}

Values are an average for two repetitions and are expressed as percentage of inhibition

\section{Enzyme activities}

By using aesculin hydrolysis for $\beta$-glucosidase activity determination, it was found that all isolates produced mycelium. Most of the isolates (27) produced spores; however, there was no relationship between $\beta$-glucosidase activity, mycelium production and sporulation. In experiments to determine esterase activity, all isolates were capable of hydrolysing Tween 80 . The determination of protease and cellulase activity showed that $79 \%$ of the isolates hydrolysed gelatin. Additionally, hydrolytic activities were measured in isolate culture filtrates. The proteinase, endochitinase and $\beta-1,3$ glucanase activities of isolates that caused higher values of inhibition against fungal plant pathogens are summarized in Table 3. The highest level of proteinase and chitinase activity was measured with isolate FCCT9 and that of $\beta-1,3$ glucanase activity was observed with isolate FCCT2.

\section{Genetic diversity of Trichoderma isolates}

Whereas the four UP-PCR primers tested yield between 4 and 8 polymorphic bands, among the twelve ISSR primers used, eight amplified more than 12 polymorphic DNA fragments (Table 4), showing consistent and reproducible banding patterns. Thus, ISSR primers were selected to analyse diversity of Trichoderma isolates. A total of 127 fragments was generated using the primers $\mathrm{CT}(\mathrm{AC})_{8}$, 
Table 3 Total enzyme activity from 48 h VMS filtrates of representative Trichoderma strains

\begin{tabular}{llcc}
\hline $\begin{array}{l}\text { Trichoderma } \\
\text { isolates }\end{array}$ & $\begin{array}{l}\text { Proteinase } \\
\text { activity } \\
\text { (U/mg) }\end{array}$ & $\begin{array}{l}\beta-1,3 \text { Glucanase } \\
\text { activity (U/mg) }\end{array}$ & $\begin{array}{l}\text { Endochitinase } \\
\text { activity (U/mg) }\end{array}$ \\
\hline FCCT2 & 15.63 & 356.27 & 37.19 \\
FCCT3 & 14.31 & 61.00 & 20.55 \\
FCCT5 & 24.25 & 1.04 & 4.39 \\
FCCT8 & 1.55 & 15.02 & 5.97 \\
FCCT9 & 66.25 & 4.86 & 40.88 \\
\hline
\end{tabular}

Values are an average for two repetitions and are expressed as units of activity per milligram of protein

Table 4 Total number of polymorphic bands generated by PCR using UP-PCR or ISSR primers from thirty three isolates of Trichoderma spp.

\begin{tabular}{ll}
\hline Primer sequence $\left(5^{\prime}-3^{\prime}\right)$ used & $\begin{array}{l}\text { Total number of } \\
\text { polymorphic bands }\end{array}$ \\
\hline UP-PCR & \\
3-2-TAAGGGCGGTGCCAGT & 8 \\
AA2M2-CTGCGACCCAGAGCGG & 8 \\
L45-GTAAAACGACGGCCAGT & 5 \\
L21-GGATCCGAGGGTGGCGGTTCT & 4 \\
ISSR & \\
CT $(A C)_{8}$ & 21 \\
$(\text { AG })_{8}$ TA & 21 \\
ACA $(C A A)_{5}$ & 17 \\
$(\mathrm{GA})_{8}$ ACC & 15 \\
$(\mathrm{AG})_{8}$ & 14 \\
$(\mathrm{AATG})_{4}$ & 14 \\
$(\mathrm{CAA})_{5} \mathrm{ACG}$ & 13 \\
TCA $(\mathrm{GT})_{8}$ & 12 \\
$(\mathrm{GCC})_{5}$ & 2 \\
$(\mathrm{AG})_{8} \mathrm{CG}$ & 0 \\
GAG $(\mathrm{CAA})_{5}$ & 0 \\
\hline
\end{tabular}

$(\mathrm{GA})_{8} \mathrm{ACC},(\mathrm{AG})_{8} \mathrm{TA}, \mathrm{TCA}(\mathrm{GT})_{8},(\mathrm{CAA})_{5} \mathrm{ACG},(\mathrm{AATG})_{4}$, $(\mathrm{AG})_{8}$ and $\mathrm{ACA}(\mathrm{CAA})_{5}$ ranging in size from 400 to $2800 \mathrm{bp}$, with an average of 14 bands per primer. A representative banding pattern using the primer $(\mathrm{AG})_{8} \mathrm{TA}$ is shown in Fig. 1. To analyse the genetic distances between isolates, a dendrogram was constructed using the DICE coefficient. Cluster analysis of ISSR data defined 20 haplotypes among the 33 isolates analysed, grouped in five clusters with an average similarity between groups of $51 \%$ (Fig. 2). The cophenetic correlation coefficient for the dendrogram $(r=0.95)$ points to an excellent fit between clustering.

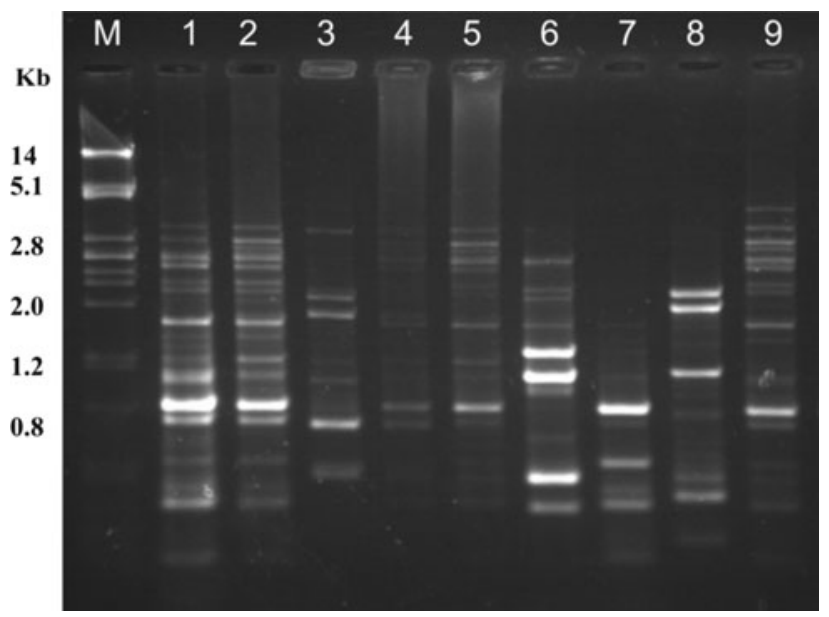

Fig. 1 PCR amplification patterns of nine Trichoderma isolates using the ISSR primer (AG) 8 TA. Lanes 1-9: FCCT1, FCCT2, FCCT6, FCCT8, FCCT9, FCCT10, FCCT14, FCCT17, and FCCT18 isolate, respectively. $M$ molecular size marker (PstI-digested $\lambda$ DNA), in kilobases $(\mathrm{kb})$

While all T. virens isolates (11) group in cluster 3, T. harzianum isolates group mainly in clusters 1,2 and 4 (7, 11 and 2 isolates, respectively). Particularly, four from the 33 isolates (FCCT10 and FCCT17, FCCT6 and FCCT7, identified as $T$. harzianum and $T$. koningii, respectively) exhibited a completely different genetic pattern, as shown in Fig. 2.

Finally, no correlation was found between morphological, biochemical or physiological features and genetic diversity of the Trichoderma isolates $(\mathrm{r}=-0.089)$.

\section{Discussion}

The integration of physiological, biochemical and molecular attributes, together with classic morphological criteria, have been used in this study to characterize a group of Trichoderma isolates from different regions of Buenos Aires Province in Argentina. From 33 isolates, three species could be certainly identified as T. harzianum, T. koningii and $T$. virens.

From the evaluation of morphological and physiological aspects there are some interesting points to be emphasized. Only T. harzianum FCCT1 was capable of producing subglobose and abundant chlamydospores of diameter more than $10 \mu \mathrm{m}$, an important feature of sporulation. As reported, chlamydospore formation and their primary importance for the survival of the fungus in the soil have a potential role in biocontrol (Chet 1987). None of the isolates grew on media at extreme $\mathrm{pH}$ values $(\mathrm{pH} \mathrm{2,10}$ or 12), which is in accordance with previous results for $T$. harzianum. The maximal linear growth of the isolates occurred at $\mathrm{pH}$ values higher than 6.5 (Papavizas 1985). In general, a 
Fig. 2 UPGMA dendrogram based on Dice (SD) similarity index illustrating the genetic relationship among thirty three Trichoderma isolates from Buenos Aires Province, Argentina

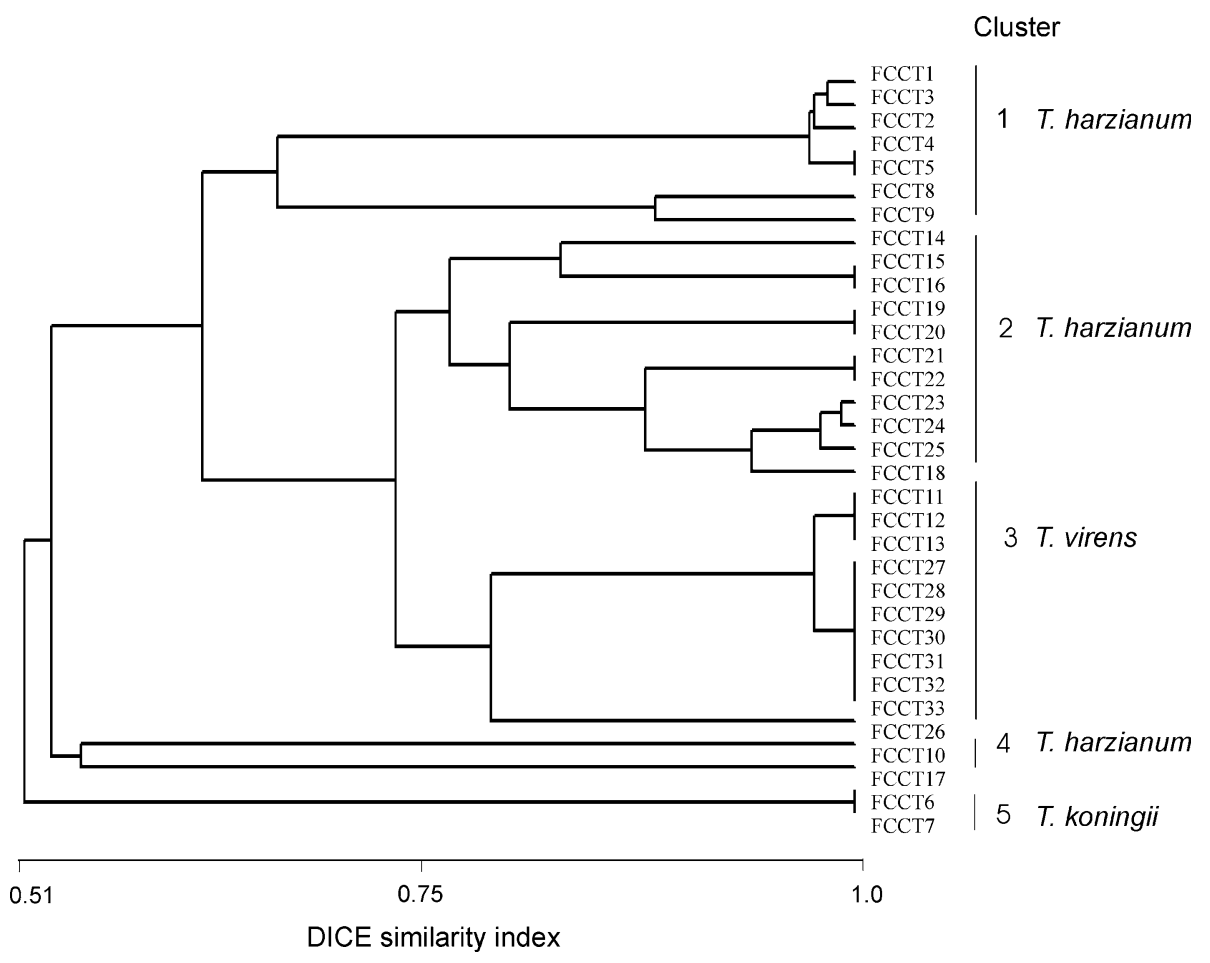

poor growth or sporulation was observed for all isolates with the different nitrogen sources tested. It has been demonstrated that with ammonium salts, glycine or urea, the medium $\mathrm{pH}$ increases, which may be ascribed to the accumulation of ammonia. Under these conditions, the fungi may be particularly prone to autolysis and release ammonium compounds (Bridge 1985). Assimilation of carbon sources showed that all isolates of Trichoderma were capable of growing on media containing different compounds. Grondona et al. (1997) evaluated several Trichoderma strains, showing that all of them were able to assimilate glucose or ethanol, and grow and sporulate in lactose as the sole carbon source. The only assay that yielded discrimination between our isolates was sporulation on lactose, which allowed differentiate $T$. koningii isolates, being the only capable of sporulating on this medium.

Development of Trichoderma isolates on different solid media for determination as $\beta$-glucosidase, esterase, protease and cellulase, have shown variations depending on enzyme activity. Whereas all isolates hydrolysed aesculin and Tween 80, 28 isolates hydrolysed gelatin. It was shown that Trichoderma spp. produce cellulase, $\beta-1-3$ glucanase and chitinase enzymes, and extracellular hydrolases that are involved in the degradation of glucans of the walls of plant pathogens (Howell 2003; Woo et al. 2006). Screening of the 33 isolates of Trichoderma spp. resulted into the identification of isolates FCCT2 and FCCT9 as the best producers of $\beta$-1-3 glucanase and chitinase, respectively. Furthermore, isolate FCCT9 produced high levels of proteinase (Table 3). These properties were partially in agreement with the aggressiveness of the different $T$. harzianum isolates against the fungal plant pathogens assayed. Particularly, FCCT2 that showed high levels of $\beta-1-3$ glucanase and chitinase, caused high inhibition against $F$. graminearum $(61 \%)$ and $F$. solani $(57 \%)$, two related fungal species. FCCT9 that showed both high proteinase and chitinase activity values was capable of causing high inhibition against $P$. oryzae $(85 \%), F$. graminearum $(61 \%)$, and $F$. solani $(57 \%)$. FCCT3 was the second best producer of $\beta-1-3$ glucanase (Table 3 ), being capable of causing high inhibition in the growth of B. sorokiniana (85\%) and $F$. solani $(57 \%)$. However, as was reported by Mischke (1996), the specific activity of proteases produced by the strains of Trichoderma did not correlate with their biocontrol ability.

On the other hand, isolates FCCT5 and FCCT8 even though they have shown high inhibition against Alternaria sp. (over 60\%), this behaviour did not correlate with the hydrolytic enzyme activity exhibited (Table 3 ). Although a direct relationship has been reported between antagonist capacity and enzyme activities of Trichoderma (Davet 1987), other studies have shown that these fungi (especially $T$. harzianum and $T$. viride) exhibit considerable variability among strains with respect to their production of lytic enzymes, biocontrol activity and host range (Sivan and Chet 1992). For example, an isolate of T. harzianum strain TH 250 produced high levels of chitinase and $\beta$-1-3 glucanase when grown on mycelia of Rhizoctonia solani, whereas it produced low levels of these enzymes on those 
of Sclerotium rolfsii (Elad et al. 1982; Grondona et al. 1997). It could be suggested that a similar mechanism could be operating between Trichoderma isolates FCCT5 and FCCT8, and Alternaria development, or that other compounds with biological activity could be being produced by these strains, causing the inhibition in the fungus growth (Sivasithamparam and Ghisalberti 1998).

Although some isolates have shown differences in growth inhibition of the five fungal isolates evaluated, T. harzianum was the most aggressive species against all phytopathogens assayed (Tables 1,2), suggesting its high potential as effective agent for the biocontrol of fungal pathogens as previously reported (Ghisalberti and Sivasithamparam 1991). Additionally, P. oryzae and B. sorokiniana were found to be the most susceptible pathogens to Trichoderma isolates used in our experiments $(85 \%$ of inhibition).

The molecular characterization of Trichoderma isolates using UP-PCR primers revealed poor information about genetic diversity among the isolates; thus, the generated data were not taken into account for further analysis. In contrast, ISSR markers allowed discrimination of molecular genetic variation among the 33 isolates. It was possible to define 20 haplotypes grouped in five clusters. T. harzianum was one of the most representative species found in this study. Eighteen isolates grouped in two main clusters (Fig. 2, clusters 1 and 2) and another two isolates that exhibited a completely different genetic pattern, grouped separately (Fig. 2, cluster 4). Our results indicate an intraspecific genetic variation among both $T$. harzianum and $T$. virens isolates, respectively. However, the origin of this molecular variation is unclear. Since Trichoderma is a diploid and heterothallic fungus (Seidl et al. 2009), different strains are likely to recombine and evolve rapidly depending on the frequencies of mating type. Furthermore, other mechanisms such as mutations, recombination and migration could explain the genetic diversity observed in this study (Chaverri et al. 2003; Sharma et al. 2009). Remarkably, cluster 1 grouped not only isolates FCCT2, FCCT3 and FCCT9, which showed high levels of hydrolytic enzyme activities and strong antagonism action but also isolates FCCT5 and FCCT8, which were capable of causing strong antagonism against Alternaria sp. but had low levels of hydrolytic enzymes (Fig. 2, Table 3).

In conclusion, a partial correspondence was observed between polymorphism patterns and aggressiveness of isolates. This discrepancy may represent an example of isolates that have arisen from one genetic line but have developed properties closer to another line perhaps through selection imposed by particular environmental or ecological conditions (Sharma et al. 2009). From the screening of the 33 Trichoderma isolates, three $T$. harzianum isolates were the most aggressive ones: FCCT2 against $F$. graminearum and $F$. solani, FCCT3 against $F$. solani and $B$. sorokiniana and FCCT9 against $P$. oryzae, $F$. graminearum and $F$. solani. This behaviour was in agreement with their extracellular hydrolytic activity levels. Further experimental work is needed to determine the effectiveness of these isolates under different field conditions and consider them as candidates for mass production as an alternative to chemical pesticides.

Acknowledgments We thank S. Stenglein for help in the collection of samples. Authors V. F. Consolo and G. L. Salerno are career investigators of CONICET (Consejo Nacional de Investigaciones Científicas y Técnicas, Argentina). C. I Mónaco and C. A. Cordo are career investigators of CIC (Prov. Buenos Aires, Argentina). This research was supported by Universidad Nacional de Mar del Plata, CONICET and FIBA.

\section{References}

Altschul SF, Madden TL, Schaffer AA, Zhang J, Zhang Z, Miller W, Lipman DJ (1997) Gapped BLAST and PSI-BLAST: a new generation of protein database search programs. Nucleic Acids Res 25:3389-3402

Baek JM, Howell CR, Kenerly CM (1999) The role of extracellular chitinase from Trichoderma virens Gv29-8 in the biocontrol of Rhizoctonia solani. Curr Genet 35:41-50

Becker JO, Schwinn FJ (1993) Control of soil-borne pathogens with living bacteria and fungi: status and outlook. Pest Sci 37: 355-363

Bindschedler LV, Sanchez P, Dunn S, Mikan J, Thangavelu M, Clarkson J, Cooper RM (2002) Deletion of the SNP1 trypsin protease from Stagonospora nodorum reveals another major protease expressed during infection. Fungal Genet Biol 38:43-53

Bornet B, Branchard M (2001) Nonanchored inter simple sequence repeat (ISSR) markers: reproducible and specific tools for genome fingerprinting. Plant Mol Biol Rep 19:209-215

Bridge PD (1985) An evaluation of some physiological and biochemical methods as an aid to the characterization of species of Penicillium Subsection Fasciculata. J Gen Microbiol 131: $1887-1895$

Bulat SA, Lübeck M, Mironenko N, Jensen DF, Lübeck PS (1998) UP-PCR analysis and ITS1 ribotyping of strains of Trichoderma and Gliocladium. Mycol Res 102:933-943

Chaverri P, Castlebury LA, Samuels GJ, Geiser D (2003) Multilocus phylogenetic structure within the Trichoderma harzianum/Hypocrea lixii complex. Mol Phylogenet Evol 27:302-313

Chet I (1987) Trichoderma - application, mode of action and potential as biocontrol agent of soilborne plant pathogenic fungi. In: Chet I (ed) Innovative approaches to plant disease control. Wiley, New York, pp 137-160

Chet I, Chernin L (2002) Biocontrol, microbial agents in soil. In: Bitton G (ed) Encyclopedia of environmental microbiology, vol. 1 NewYork. Wiley, pp 450-465

Consolo VF, Cordo CA, Salerno GL (2008) DNA fingerprint and pathotype diversity of Pyricularia oryzae populations from Argentina. Austr Plant Pathol 37:357-364

Cumagun CJR, Hockenhull J, Lübeck M (2000) Characterization of Trichoderma isolates from Philippine rice fields by UP-PCR and rDNA-ITS1 analysis: identification of UP-PCR markers. J Phytopathol 148:109-115

Dal Bó E, Nome SF, Álvarez S, Colombo MDH, Flores CR (2010) Enfermedades de Solanum lycopersicum L. (tomate). In: Nome 
SF, Docampo DM, Conci LR (eds) Atlas Fitopatológico Argentino Córdoba, Argentina. URL: http://www.fitopatoatlas.org.ar/

Davet P (1987) Criteres de selection de clones de Trichoderma antagonists de champignons telluriques a sclerotes. EPPO Bull 17:535-540

de la Cruz J, Toro-Pintor JA, Benitez T, Llobell A (1995) Purification and characterization of an endo-beta-1, 6-glucanase from Trichoderma harzianum that is related to its mycoparasitism. J Bacteriol 177:1864-1871

Elad Y, Chet I, Henis Y (1981) A selective medium for improving quantitative isolation of Trichoderma spp. from soil. Phytoparasitica 9:56-67

Elad Y, Chet I, Henis Y (1982) Degradation of plant pathogenic fungi by Trichoderma harzianum. Can J Microbiol 28:719-725

Galich MT (1997) Fusarium head blight in Argentina. In: Duvin HJ, Gilchrist R, Reeves J, McNab A (eds) Fusarium Head Scab: global status and future prospects. Centro Internacional de Mejoramiento de Maíz y Trigo, Mexico, pp 19-28

Ghisalberti EL, Rowland G (1993) Antifungal metabolites from T. harzianum. J Nat Prod 56:1799-1804

Ghisalberti EL, Sivasithamparam K (1991) Antifungal antibiotics produced by Trichoderma spp. Soil Biol Biochem 23:1011-1020

Grondona I, Hermosa MR, Tejada M, Gomis MD, Mateos PF, Bridge PD, Monte E, Garcia-Acha I (1997) Physiological and biochemical characterization of Trichoderma harzianum, a biological control agent against soil borne fungal plant pathogens. Appl Environ Microbiol 63:3189-3198

Harman GE, Howell CR, Viterbo A, Chet I, Lorito M (2004) Trichoderma species-opportunistic, avirulent plant symbionts. Nat Rev Microbiol 2:43-56

Howell CR (2003) Mechanisms employed by Trichoderma species in the biological control of plant diseases: the history and evolution of current concepts. Plant Dis 87:4-10

Kubicek CP, Mach RL, Peterbauer CK, Lorito M (2001) Trichoderma: from genes to biocontrol. J Plant Pathol 83:11-23

Kuhls K, Lieckfeldt E, Börner T (1995) PCR-fingerprinting used for comparison of ex type strains of Trichoderma species deposited in different culture collections. Microb Res 150:363-371

Kullnig C, Mach RL, Lorito M, Kubicek CP (2000) Enzyme diffusion from Trichoderma atroviride (T. harzianum P1) to Rhizoctonia solani is a prerequisite for triggering of Trichoderma ech 42 gene expression before mycoparasitic contact. Appl Environ Microbiol 66:2232-2234

Leger RJ, Cooper RM, Charnley AK (1987) Production of cuticledegrading enzymes by the entomopathogen Metarhizium anisopliae during infection of cuticles from Calliphora vomitoria and Manduca sexta. J Gen Microbiol 133:1371-1382

Leuchtmann A, Petrini O, Samuels GJ (1996) Isozyme subgroups in Trichoderma section Longibrachiatum. Mycologia 88:384-394

Lorito M, Woo SL, Scala F (2004) Le biotecnologie utili alla difesa sostenibile delle piante: i funghi. Agroindustria 3:181-195

Lynch MJ, Slater JH, Bennett JA, Harper SHT (1981) Cellulase activities of some aerobic microorganisms isolates from soil. J Gen Microbiol 127:231-236

Mantel NA (1967) The detection of disease clustering and a generalized regression approach. Cancer Res 27:209-220

Markovic O, Markovic N (1998) Cell cross-contamination in cell cultures: the silent and neglected danger. In Vitro Cell Dev Biol $34: 1-8$

Mischke S (1996) Evaluation of chromogenic substrates for measurement of protease production by biocontrol strains of Trichoderma. Microbios 87:175-183

Moreno MV, Stenglein SA, Balatti PA, Perelló AE (2008) Pathogenic and molecular variability among isolates of Pyrenophora triticirepentis, causal agent of tan spot of wheat in Argentina. Eur $\mathbf{J}$ Plant Pathol 122:239-252
Murray MG, Thompson WF (1980) Rapid isolation of high molecular weight plant DNA. Nucleic Acid Res 8:4321-4325

Papavizas GC (1985) Trichoderma and Gliocladium: biology, ecology and potential for biocontrol. Annu Rev Phytopathol 23:23-54

Rohlf FJ (1998) NTSYS-PC version 2.0. Numerical taxonomy and multivariate analysis system. Exeter Software: Setauket, NY

Samson RA (1995) Constraints associated with taxonomy of biocontrol fungi. Can J Bot 73:83-88

Samuels GJ, Chaverri P, Farr DF, McCray EB (2009) Trichoderma online, systematic mycology and microbiology laboratory, ARS, USDA. http://nt.ars-grin.gov/taxadescriptions/keys/TrichodermaIndex. cfm (verified Aug 12, 2009)

Seidl V, Seibel C, Kubicek CP, Schmoll M (2009) Sexual development in the industrial workhorse Trichoderma reesei. Proc Natl Acad Sci USA 106:13909-13914

Sharma K, Mishira AK, Misra RS (2009) Morphological, biochemical and molecular characterization of Trichoderma harzianum isolates for their efficacy as biocontrol agents. J Phytopathol 157:51-56

Sivan A, Chet I (1992) Microbial control of plant disease. In: Mitchell $\mathrm{R}$ (ed) New concepts in environmental microbiology. WileyLiss, New York, pp 335-354

Sivasithamparam K, Ghisalberti EL (1998) Secondary metabolism in Trichoderma and Gliocladium. In: Kubicek CP, Harman GE (eds) Trichoderma and Gliocladium, vol 1. Taylor and Francis, London, pp 139-191

Sneath PHA, Sokal RR (1973) Numerical taxonomy. The principles and practice of numerical classification. WH Freeman, San Francisco, CA

Stasz TE, Nixon K, Harman GE, Weeden NF, Kuter A (1989) Evaluation of phenetic species and phylogenetic relationships in the genus Trichoderma by cladistic analysis of isozyme polymorphism. Mycologia 81:391-403

Stenglein SA, Balatti PA (2006) Genetic diversity of Phaeoisariopsis griseola in Argentina as revealed by pathogenic and molecular markers. Physiol Mol Plant Pathol 68:158-167

Turner D, Kovacs W, Kuhls K, Lieckfeldt E, Peter B, Arsian-Atac I, Strauss J, Samuels GJ, Borner T, Kubicek CP (1997) Biogeography and phenotypic variation in Trichoderma sect. Longibrachiatum and associated Hypocrea species. Mycol Res 101:449-459

Vinale F, D'Ambrosio G, Abadi K, Scala F, Marra R, Turra D, Woo SL, Lorito M (2004) Application of Trichoderma harzianum (T22) and Trichoderma atroviride (P1) as plant growth promoters, and their compatibility with copper oxychloride. J Zhejiang Univ Sci 30:2-8

Viterbo A, Ramot O, Chermin LY, Chet I (2002) Significance of lytic enzymes from Trichoderma spp. in the biocontrol of fungal plant pathogens. Anton Leeuw Int J G 81:549-556

Watts RJ, Chaudhary DK, Tauro P (1988) Isolation and characterization of a new antifungal metabolite of Trichoderma reesei. Plant Soil 107:81-84

White TJ, Bruns T, Lee S, Taylor JW (1990) Amplification and direct sequencing of fungal ribosomal RNA genes for phylogenetics. In: Innis MA, Gelfand DH, Sninsky JJ, White TJ (eds) PCR protocols: a guide to methods and applications. Academic Press, Inc., New York., pp 315-322

Woo SL, Scala F, Ruocco M, Lorito M (2006) The molecular biology of the interactions between Trichoderma spp., phytopathogenic fungi, and plants. Phytopathology 96:181-185

Zimand G, Valinsky L, Elad Y, Chet I, Manualis S (1994) Use of RAPD procedure for the identification of Trichoderma strains. Mycol Res 98:531-534 